\section{E A Institute of \\ YK Business Administration \\ 光 \\ Karachi \\ Leadership and Ideas for Tomorrow}

\section{Business Review}

Volume 10 Issue 2 July-December 2015

7-1-2015

\title{
Back Matter of Volume 10 Number 2
}

Tufail A. Qureshi

Institute of Business Administration, Karachi

Follow this and additional works at: https://ir.iba.edu.pk/businessreview

Part of the Business Commons

c) (i)

This work is licensed under a Creative Commons Attribution 4.0 International License.

\section{Recommended Citation}

Qureshi, T. A. (2015). Back Matter of Volume 10 Number 2. Business Review, 10(2). Retrieved from https://doi.org/10.54784/1990-6587.1363

This article is brought to you by iRepository for open access under the Creative Commons Attribution 4.0 License and is available at https://ir.iba.edu.pk/businessreview/vol10/iss2/14. For more information, please contact irepository@iba.edu.pk. 


\title{
BUSINESS REVIEW
}

\author{
Research Journal \\ of \\ The Institute of Business Administration \\ Karachi, Pakistan
}

\section{Guidelines for Contributors}

Business Review is a biannual publication of the Institute of Business Administration, Karachi, Pakistan. It is a multidisciplinary journal covering a wide range of issues in the areas of business, social and management sciences, administration and governance, mathematics and computer studies, finance, economics, psychology, business ethics, logic, history of ideas, and philosophy of comparative religion.

\section{Guidelines for Authors}

1. Business Review invites the following types of contributions:

- Research papers

- Case studies and discussion papers

- Articles / Book Reviews

- Brief reports and comments

2. Manuscript should be submitted to the Editor, Business Review, Institute of Business Administration, University Road, Karachi, Pakistan.

3. Three copies of the manuscript should be submitted.

4. The text should be double spaced, on one side of the quarto paper allowing wide margins for referee's comments.

5. All illustrations, tables, etc., should be placed on separate sheets, included with each copy. Their placement should be indicated in the text.

6. Footnotes should be numbered consecutively through the text.

7. The first page of the manuscript should contain the following information. (i) title of the paper; (ii) the names(s) and institute affiliation(s) of the author(s); (iii) a footnote should give the name, postal address,telephone and fax number, and an email address of the authors.

8. The second page must contain the title, and abstract not exceeding 300 words, a maximum of 5 key words or phrases and appropriate JEL codes to be used for indexing purpose. The text will start on page number 3 .

9. Acknowledgements of all sorts should be included on the first page

10. All mathematical derivations should be presented on a separate sheet, (not to be published) to help the referees.

11. Manuscript should include only those references that are cited in the text. Authors are advised to follow American Psychological Association (APA) style of referencing.

12. All literary material, including books, journals and manuscripts for review should be submitted in triplicate to the Editor, Business Review, Institute of Business Administration, University Road, Karachi, Pakistan.

13. It is assumed that the paper submitted is an original unpublished work and it has not already been published or submitted for publication elsewhere.

14. The opinions, ideas and evaluations expressed in the articles printed in the Business Review do not necessarily represent the views or policies of The Institute of Business Administration or the Editorial Board. They should be considered as representative example of opinions and analysis now current in the academic field on various subjects of intellectual, educational and cultural interest.

15. After internal evaluation, the Editor will send the selected articles to the external referees or the consulting foreign editors for their evaluation. Selection of the referees will be the discretion of the Editor.

16. The articles will be evaluated through anonymous peer reviews. Papers will normally be scrutinized and commented on by at least two independent expert referees in addition to the Editor. The referees will not be made aware of the identity of the author. All information about authorship will be removed from the papers.

17. The text of this publication or any part thereof may not be reproduced in any form or manner whatsoever without the permission in writing from the Editor.

For advance electronic submission of the material:

Main Campus: University Road, Karachi. Tel: (92-21) 38104700 Fax: (92-21) 99261508

City Campus: Garden/Kiyani Shaheed Road, Karachi.

Website: www.lba.edu.pk Email: tqureshi@iba.edu.pk

Published by iRepositorjo June 2021to the Editor, Business Review, Research Journal of The Institute of Business Administration, Karachi, Pakistan. 


\section{IBA \\ 戉 \\ Institute of
Business Administration
Karachi-Pakistan \\ Leadership and Ideas for Tomorrow}

Who are the leaders? What are the leaders made of? Who are the men and women who "made it happen" for themselves and the people around them? How did they overcome obstacles? Where did they discover opportunities? This is critically important information for anyone who aspires to financial success, personal satisfaction, and the sense of accomplishment that comes when potential turns into actuality.

Our purpose here is something much more than theoretical or intellectual understanding of leadership. You' re going to learn what leaders have done so that you can start doing it yourself, right away, in your own life and career. That's leadership mastery. It's putting what you learn into action. A leader's philosophy is simply the fundamental purposes and principles with which he or she identifies. Different leaders have different ideas about leadership. But anyone who studies the experience of contemporary business and organizational leaders, certain points emerge. There are key principles of leadership...

- Leadership is helping people achieve a shared vision, not telling people what to do.

- Loyalty to leadership relies on the leader's connection and understanding of people's needs, wishes, and possibilities. Solutions to leadership challenges do not lie in the leader's needs and wishes. Leadership solutions lie in the needs and wishes of the followers...

So what do people really want? Not really so many things; health and the preservation of life, food and shelter, a certain amount of money and the things money will buy, the well-being of their children, and a fundamental sense of their own significance. All these are relatively easy to gratify... except for the last one. This longing is almost as deep and insistent as the desire for food and water. John Dewey called it "the desire to be important". Freud went further and called it "the desire to be great". Positive motivation means giving people a real sense of purpose, a feeling that they are working toward a valuable, attainable, and mutually important goal.

Dale Carnegie, Leadership Mastery, PP 1-34 